\title{
The role of adult education in national development
}

\author{
Yilben James Jinna ${ }^{1}$, P. N. Maikano ${ }^{2}$ \\ ${ }^{1}$ General Studies Education Department, Federal College of Education, Pankshin, Nigeria \\ ${ }^{2}$ Curriculum Department, Federal College of Education, Pankshin, Nigeria
}

\begin{abstract}
Adult and non-formal education has been apparently much neglected aspect of educational activities in the country. This neglect could be traced to our colonial heritage where the British colonial masters and the early missionaries who pioneered education in the African continent paid attention only to formal education to train clerks and interpreters in Government service and commercial houses; and catechists in the church. The complication and the problem of organizing and administering non-formal education is yet another reason for the neglect.
\end{abstract}

Keywords: education; colonial heritage; missionaries; Africa

\section{INTRODUCTION}

Adult education in Nigeria is presently geared towards national development (Ewuzie, 2012). The objective of the process of adult education and national development is to get the adults, either as individuals or as a group, to learn and through learning to change their attitude and behaviour. The policy on education states the objectives of adult education as:

1. To provide functional literacy education for adults who have never had the opportunity of any formal education

2. To provide functional and remedial education for those young people who prematurely dropped out of the formal school system

3. To provide further education for different categories of completers of formal education system in order to improve their basic knowledge and skills

4. To provide in-service and on-the-job vocational and professional training for different categories of workers and professionals in order to improve their skills

5. To give the adult citizens of the country aesthetic, cultural and civic education for public enlightenment.

Monye (1981) opines that all these objectives have one end in view-to equip the adult with everything he needs for life in order to be relevant to his society by helping to solve some of its problems. We have to recognize that development is of man, by man and for man. Man is the master of his destiny and adult education serves to bring about a fundamental change in man's attitudes and lifestyle. To survive, people must have awareness and to become aware, they must be literate. 


\section{EDUCATION}

\section{1. Adult Education}

Adult education usually refers to any form of learning undertaken by or provided for mature men and women outside the formal school system. The main targets are specifically defined as youth (girls and boys over 15 years of age, but sometime younger) as well as women and men, generally poor or socially disadvantaged. Although literacy continues to be at its heart, adult education also includes "numeracy", problem-solving and life skills, and other knowledge. The notion of adult education is often used interchangeably with other notions such as literacy, adult basic education, lifelong learning, continuing, adult basic end non-formal education, etcetera. For the purpose of this presentation, adult education is understood as a transmission process of general, technical or vocational knowledge, as well as skills, values and attitudes, which takes place out of the formal education system with a view to remedying early education inadequacies of mature people or equipping them with the knowledge and cultural elements required for their self-fulfilment and active participation in the social, economic and political life of their societies (Seya, 2014).

The concept of development is complex as it has several connotations. However, Allen (2000) has identified three main meanings in which development is generally used, namely: (i) as a vision, description or measure of the state of being of a desirable society; (ii) as an historical process of social change in which societies are transformed over long periods; and (iii) as consisting of deliberate efforts aimed at improvement on the part of various agencies, including governments, all kinds of organisations and social movements. For the purpose of this presentation, development will be referred to as a process of economic, social, political and cultural change engineered in a given society by the efforts of all stakeholders, both internal and external - including the local communities, the Government, the private sector, the civil society organisations, the NGOs and the technical and financial development partners- with a view to improving the conditions of the life of the population in a sustainable way. Implicit in these definitions is the assumption that development requires, interalia, the formation of human capital and social capital, some of the main factors of production required for a broad-based economic growth that provides the ground for sustainable poverty reduction.

\section{2. Adult Education and Development}

The role of adult education in national development is multi-dimensional. Indeed, as are of the building blocks of human development, and not just a basic right, education, including adult education, is a foundation for progress in areas such as human capital, health, nutrition and the development of institutions and democracy. Therefore, the role of adult education in development can be apprehended through the complex relationships existing between all its forms and the economic, political, social and cultural determinant factors of Nigerian development in particular and Africa as a whole. The economic role of adult education in development is apparent in its contribution to human capital formation. It is now well established that, alongside health care, sanitation, and nutrition that improve people's standard of living and productivity by reducing sickness and mortality rates and by increasing life expectancy, adult basic education, by equipping recipients with essential literacy and numeracy skills, yields high rates on investment, thereby enhancing labour productivity. An educated population also provides a more attractive investment climate. Thus, investment in the development of human capital, through adult education, is crucial for developing a labour force and managerial know-how, able to compete in today's global economy (Seya, 2014). 
Formal education alone is not sufficient for playing this role as even those categories of the population who have had formal education and training might need to be updated and reskilled through adult education, mainly because today's knowledge society tends to render previously acquired knowledge and skills inappropriate and obsolete. Adult education is also instrumental in familiarising the active population of Nigeria with Information Communication Technology (ICT), a decisive tool for the smooth integration of Nigerian economies in the global economy. The importance of this cannot be overemphasised as the world is rapidly moving towards knowledge-based economic structures and information societies that comprise networks of individuals, firms, and countries linked electronically in inter-dependent and interactive relationships.

Adult education also plays a major role in social development. It is now widely admitted that growth will not reduce poverty unless poor people are able to actively participate in it. Such participation can become effective to a large extent through adult education. Indeed, the African, and of course, Nigerian population will need some kind of formal and non-formal education and training to be able to benefit from basic health care, including sexual and reproductive health services, the development of new medicines, and thus be in a position to free itself from diseases that devastate poor people, such as HIV/AIDS, tuberculosis, malaria and other parasites. Adult education will also be needed to enable the Nigerian poor to really take advantage of programmes aimed at protecting orphans and vulnerable children or drastically reducing the number of people without access to safe water and basic sanitation.

The role of adult education in development is not limited only to economic and social spheres. It also has a political dimension. There is a strong link between adult learning and democracy. This is so because, as acknowledged at the UNESCO Fifth International Conference on Adult Education held in Hamburg in 1997, "substantive democracy and a culture of peace are not given; they need to be constructed "(UNESCO, 1997). For democracy to be achieved, adult education is needed as to inform them of their rights and responsibilities as democracy also requires people to actively participate at local, national and global levels. It is today admitted that the lack of recognition of the need to involve civil society, especially grassroots organisations, by giving them a voice in decision-making and the means to participate effectively in society is one of the major causes of development failure in many African countries. Abuse of human rights and social injustice leading to the exclusion of important segments of society, have also constituted stumbling blocks to economic and social progress on the continent and paved the way to violent conflicts (Seya, 2014).

Adult education may prove to be a powerful tool for favouring inclusive development through democracy, thereby ensuring peace and stability, as a number of studies have shown that prevention (through adult education) is much more effective than intervention. Prevention of political disorders and civil unrest can be made possible through various adult education strategies. A number of adult education policies promote democracy and peace have been proposed during the Fifth International Conference on Adult education (UNESCO, 1997). They tend to attain their objectives through various strategies that promote an active civil society, reinforce gender democracy and help to solve conflicts between different countries and groups to the extent that the world at large is experiencing the effects of multi-faceted globalization with varying degrees of impact on peoples and cultures. It is apparent from the foregoing that adult education is an indispensable vector for social, economic and political progress in any society. 


\section{3. Wider Benefits of Adult Education}

Over the last few years, political as well as scientific debates have stressed the growing importance of adult education. There prevails a consensus that adult education plays a significant role in promoting personal, social and economic well-being, which has also long been recognised by DVV International. There is a deep rooted belief that adult learning has the potential to create personal, economic and social value (Motschilnig, 2014). This paper argues that adult education affects people's lives in ways that go for beyond what can be measured by the labour market earnings and economic growth. Important as they are the wider benefits of adult learning are neither currently well understood nor systematically measured.

\section{4. Economic Benefits of Adult Education}

Adult learning can improve employability and income, which is a key pathway to realising a range of other benefits. For example, it enables people to some extent, choose and shape the context in which they live and work and even increase their social status.

\section{5. Health}

Empirical evidence has found that adult learning can have both transforming and sustaining effect on health. Transforming effects are when adult learning changes health behaviour (for instance from smoking to non-smoking) while sustaining effects are when health behaviour is maintained, for example, the likelihood of remaining a non-smoker. Therefore, people attending Adult education courses are more likely to have healthy lifestyles, and there is a body of literature which describes adult learning and its relation to mental health. Also, inter-generational effects of educated parents on the health of their children are very relevant Manninen (2008).

\section{6. Civic and Social Engagement}

Many countries share a concern about declining levels of voter participation and about the state of civic participation. It is possible that adult learning might inspire a change in attitude, which in turn brings about a change in behaviour. Several studies (OECD, 2007; Desjardins \& Schuller, 2006, 2006; Field, 2009) amongst others show that learning can promote social cohesion and strengthen citizenship. Adult learning may support the development of shared norms, greater trust towards other individuals and the government and more civic co-operation.

\section{7. Attitudes Change}

An individual who participate in adult learning may differ from the one who does not in terms of prior attitude. It was found (Feinsteinet al, 2003) that adult learning is associated with more "open-minded" perspectives on race and authority, greater understanding of people from different backgrounds, challenging previously held beliefs and with a sustaining effect on nonextremist views. Especially academic oriented courses are most suited for opening minds and generally link adult learning to increased racial tolerance, a reduction in political cynicism and a higher inclination towards democratic attitudes.

\section{8. Educational Progression}

Progression into other learning is an important outcome of adult education. There is clear a evidence that (successful) engagement in learning provides incentive for further learning. 
Manninen (2010) found that 93 percent of course participants said that their participation has motivated them to learn more. Further, learners described their progress by referring to real life activities they could now do in a wide variety of life contexts (everyday and leisure practice, work) community and educational practice). Self-confidence, finding voice and opening up to learning were identified by almost all learners and seemed central to their perspective on learning. These outcomes provided improvement in the quality of their lives and become part of their learner identity.

\section{9. Poverty Reduction}

Although inadequately understood, adult education has been cited as a key in reducing poverty levels around the world (UNESCO-UIL, 2009 in EAEA, 2010) as it has the capacity to positively affect may dimensions of poverty. Results show that adult education has a role to play in nurturing the skills and knowledge necessary to both reducing the risk of poverty, but also for providing the capacity to withstand poverty-inducing pressures. EAEA (2010) underlines the empowering role that adult education can have in times of crises, providing a stable community, a chance for reorientation, a safe place and social recognition. Also, the United Kingdom, the Inquiry into the Future of Lifelong Learning (IFLL) (Sabates, 2008) concludes that participating in adult learning can help substantially to reduce poverty through enhancing employment prospects, improving health levels of poor people and giving better chances of acquiring the tools needed to run their own lives. Therefore, it should be a part of any approach to reducing poverty, as multiple initiatives are needed to lift people out of poverty.

\section{10. Main Gaps and Shortcomings}

Reviewing the literature and research on the benefits of adult learning, some shortcomings were identified:

1. Gaps in Knowledge Base: First of all, only a few studies focus on adult learning and its learning experiences that matter for wider benefits, which mean that there are substantial gaps in our knowledge base on the potential impacts on adults learning (Motschilnig, 2014).

2. Focus on attainment in formal education: There is a focus of empirical evidence on formal education attainment, without considering non and informal learning. Most studies focus on the number of years/months or level of educational attainment and formal qualifications as an indicator of output mainly because these kinds of data are cheaply and easily collectable.

3. Focus on human capital and economic outcomes: So far human capital theory has linked education to economic outcome, and still the emphasis very often lies on the economic benefits of learning.

4. Focus on vocational training: Moreover, data is primarily available for vocational training. Little research and specific evidence exists on general and leisure adult learning. There is no empirical evidence exactly how and which types and approaches of learning interventions are most effective and generate higher benefits for adults.

5. Transferability: Another issue is the transferability of results between regions as well as between types of adult education provision within the sector itself. Also, international results of studies often cannot be compared, since the instruments and 
national meanings of adult education differ considerably from one country to the other.

6. Methodological challenges: Finally, methodologically, the analysis of learning benefits is changing as it is seemingly hard to quantify the impact of adult education. Often times, the benefits evaluation is based on subjective valuations and learners' responses to surveys and interviews. Most of the studies focusing on adult education are either small-scale data sets containing information on adult education are in development, in most countries representative longitudinal studies with the main focus on educational issues do not exist (Motschilig, 2014).

\section{CONCLUSIONS}

It has been argued in this paper that adult education, referred to broadly as a transmission process of general, technical or vocational knowledge, as well as skills, values and attitudes mean for mature people, is a powerful tool for development, including poverty reduction, civic and social engagement. Adult education has been often recognised, in theory, as necessary to enhance development, especially in an era of globalization, not only because it produces human capital, but also because it enables people to become well-informed citizens, capable of thinking critically and owning their destiny through active participation. Unfortunately, this recognition has not often been translated on the ground into substantial and relevant programmes.

The low amounts of budgetary resources devoted to adult education by African countries reflected the low priority given to this education sub-system by the donor community, despite its inclusion in the global development initiatives adopted since the $90 \mathrm{~s}$. If this trend continues, Africa as a whole and Nigeria in particular will be deprived again of a significant human resources so much needed to meet its development challenges. Such as scenario should not be allowed to happen, otherwise the ensuring social, economic and political consequences would be catastrophic for a continent that already represents the most impoverished part of the world.

\section{Recommendations}

Resulting from the investigation for this paper, some recommendations for possible future courses of action can be made:

1. Holistic View: There is still a call for a holistic attitude, beyond qualifications, certifications and economic benefits.

2. Further Research and Data Collection: One of the main challenges to research and evaluation in the adult education sector is the huge complexity and diversity of educational provision. Therefore, it will be essential to provide better research, data collection and analysis. More coherent studies for understanding the effects and causes of (adult) learning need to be developed.

3. Development of Indicators: Indicators should be developed, which provide useful information for (inter)national policy makers, because wider benefits are difficult to measure quantitatively and more complex than one single data set. Indicators are important tool in order to assess benchmarks and to monitor the educational system..

4. More Investment: It was clear from the consultation undertaken for this study that future research will depend on convincing government and research funding bodies. There is need to invest in the quality of adult learning provision. 


\section{References}

[1] Allen D. (2013). Change in Adult Education in Nigeria http://www.eaea.org/index.php?k=12095.

[2] Desjardins R., Schuller T. (2006). Understanding the Social Outcomes of Learning in Measuring the Effects of Education on Health and Civic Engagement: Proceedings of the Copenhagen Symposium, Paris: OECD.

[3] European Association for the Education of Adults (2010). The Role of Adult Education in Reading Poverty EAEA Policy Paper Brussels: EAEA.

[4] Ewuzie R. (2012). Change in Adult Education in Nigeria. http://www.eaea.org/index.php?K=12095.

[5] Feinstein L., Hammond C., Woods L., Preston J., Bynner J. (2003). The Contribution of Adult Learning to Health and Social Capital, London: Centre for Research on the Wider Benefits of Learning.

[6] Field J. (2009). Well-being and Happiness. IFLL Thematic Paper 4, London: NIACE.

[7] Manninen, J. (2010). Wider Benefits of Learning within Liberal Adult Education System in Finland. University of Eastern Finland.

[8] Manninen J. (2008). Change in Adult Education in Nigeria. http://www.eaea.org/index.php?K=12095.

[9] Monye C. (1981). Change in Adult Education in Nigeria. http://www.eaea.org/index.php?K=12095.

[10] Motschilnig R. (2014). Wider Benefits of Adult Education - An Inventory of Existing Studies and Research.

http:www.dvv-international.de/index.php?articleid=1321\&clang=1.

[11] OECD (2007). CERI-Understanding the Social Outcomes of Learning, Paris: OECD.

[12] Sabates R. (2008). The Impact of Lifelong Learning on Poverty Reduction. IFLL Public Value Paper 1, London: NIACCE.

[13] Seya P. T. (2014). Adult Education and African Development in the Context of Globalization. http://www.dvv-international.de/index.php?article-id=230\&clang=1.

[14] UNESCO (1997). Final Report of the Fifth International Conference on Adult Education. UNESCO: Hamburg.

[15] Abdulrahaman W. Lawal, International Letters of Social and Humanistic Sciences 3 (2014) 53-59.

[16] Alaba E. Dare, International Letters of Social and Humanistic Sciences 3 (2014) 73-79.

[17] Grema Maina Bukar, Yohanna A. Timothy, International Letters of Social and Humanistic Sciences 4 (2014) 9-21.

[18] Akor Isaiah Akem, Victor Tavershima Ukeli, International Letters of Social and Humanistic Sciences 4 (2014) 49-59.

[19] Sule Maina, International Letters of Social and Humanistic Sciences 4 (2014) 87-96. 
[20] Odo John Ogar, International Letters of Social and Humanistic Sciences 8(1) (2014) 2 8-33.

[21] Elizabeth Morenikeji Titilayo Adediran, Albert Oluyomi Kehinde, International Letters of Social and Humanistic Sciences 8(1) (2014) 66-75.

[22] S. A. Kazeem, K. Y. Balogun, International Letters of Social and Humanistic Sciences 8(2) (2014) 108-119.

[23] Sanusi L. Sa'adatu, International Letters of Social and Humanistic Sciences 8(2) (2014) 140-147.

[24] Rowland U. Aleshi, Clementina N. Iloh, International Letters of Social and Humanistic Sciences 8(3) (2014) 208-216

[25] Hannatu Abdullahi, International Letters of Social and Humanistic Sciences 8(3) (2014) 217-223.

[26] Fowoyo Joseph Taiwo, International Letters of Social and Humanistic Sciences 8(3) (2014) 244-251. 